\title{
The Impact of Professional Allowances for Teachers and Academic Supervision of Madrasah Principals on Teacher Success at MA Negeri 1 Prabumulih
}

\author{
Sumartini $^{1 *}$, Happy Fitria ${ }^{2}$, Rohana ${ }^{2}$
}

\author{
${ }^{1}$ MI Negeri 1 Prabumulih \\ ${ }^{2}$ Universitas PGRI, Palembang, Indonesia \\ *Corresponding author. Email: sumartini230366@gmail.com
}

\begin{abstract}
The purpose of this study is to evaluate the impact on the output of teachers at MA Negeri 1 Prabumulih City of the effect of the professional allowances and academic supervision of the head of the madrasah. Research was conducted in the MA Negeri 1 Prabumulih City area of Prabumulih City. This type of study is quantitatively descriptive. The sample in the study consisted of 54 respondents with data collection techniques in the form of a questionnaire (questionnaire). The findings show that: 1) there is an impact of professional allowances on the performance of teachers; 2) there is an effect of academic supervision of madrasah principals on the performance of teachers; 3 ) there is an influence on the performance of teachers between professional allowances and academic supervision of madrasah principals.
\end{abstract}

Keywords: Teacher's Professional Allowance, Academic Supervision of the Principals of Madrasah, Teacher's Success

\section{INTRODUCTION}

National education has placed teachers as vocational educators with the key role of educating, teaching, directing, guiding, preparing, assessing and evaluating students in early childhood education through formal education, basic education and secondary education. Education is the most key factor for the development of the nation [1]. Teachers, as a human element in education and as a person who provides knowledge to students, must really understand the basic principles, objectives and policies of education. Equipped with this knowledge, the teacher has the basis to do his job. In the process of teaching and learning interaction, the teacher is the person who offers information and skills to students.

In addition, the poor performance of school teachers is affected by a number of factors, including competence, work morale, work discipline, job satisfaction, the teaching organization, the leadership of the school principal, as well as the nature of government policies on education. This is consistent with the view of Kasmir [2] that the performance of teachers is affected by a variety of factors, including: work environment, organizational culture, leadership, work motivation, work discipline, pay, job satisfaction and other factors. Teacher efficiency would be optimal if it is incorporated with the school elements, whether they are the principal or students. The effectiveness of schools in improving the level of education is a shared responsibility between teachers and school principals [3].

Thus, the performance of teachers has a direct influence on the quality of each student's education. The better the performance of the teacher, the better the quality of the education provided. Successful teachers can indeed make significant students [4]. In other words, if the teacher has a good performance, the outcomes of the teaching and learning process would also be good. This success plays an important role in achieving the desired teaching objectives. In view of the essential role of performance, schools need to enhance the performance of teachers in order to optimize the achievement of teaching objectives.

National education has placed teachers as vocational educators with the key role of educating, teaching, directing, guiding, preparing, assessing and evaluating students in early childhood education through formal education, basic education and secondary education. 
Modern education carries the fate of accountability for destructive developments in the moral and spiritual domain of humanity [5]. Law of the Republic of Indonesia Number 14 of 2005 states that teaching success in schools has an important role to play in achieving school objectives. One of the factors that decides school goals is the success of the teacher. This is an absolute necessity for the development of a quality education and system. The enactment of this law shall have three purposes. First, as a legal foundation for teachers by arbitrary behavior by students, parents and society. Second, to strengthen the professionalism of teachers. Third, to improve the welfare of teachers through the provision of professional allowances. Muslich's [6].

Ethymologically, the professional allowance derives from the term allowance and the occupation. Actually, allowances are money or goods used to sustain extra revenue outside of salary as assistance or support. In the meantime, the profession is basically an area of work focused on some skills education (skills, vocational). Thus, it can be inferred that the professional allowance is an additional benefit above the standard salary provided to a person who works on the basis of professional or professional expertise in a given field.

According to Law No. 14 of 2005 on Teachers and Teachers Article 16 Paragraph 1 of Law No. 14 of the Republic of Indonesia of 2005 provides that the Government shall award professional allowances to teachers who already have educational qualifications appointed by educational providers and/or communitybased educational units. In addition, it is specified in paragraph 2 that the professional allowance shall be equal to the basic salary of one teacher appointed by the educational unit administered by the Government or the Regional Government at the same level, period of service and qualifications. Article 16 Paragraph 3 of the Law of the Republic of Indonesia Number 14 Year 2005 provides that the professional allowance for teachers is provided in the budget for State revenue and expenditure (APBN) and/or the budget for regional revenue and expenditure (APBD). It is mentioned that the professional allowance in question is an extra payment equivalent to $1 \mathrm{x}$ the basic salary of the teacher at the same level, years of service and qualifications distributed from the APBN and/or APBD funds.

The Trained Teacher Allowance is a promising government initiative for teachers. The Government aims to increase the motivation and efficiency of teachers and boost the quality of living of teachers. This dream has been realized for a long time after the Government released Permendiknas No. 18 of 2007 on the Certification of In-Service Teachers, 4 May 2007, and Decree No. 057/0/2007 of the Minister of National Education on the Commitment of Higher Education
Institutions Organizing In-Service Teacher Certification, 13 July 2007.

Whereas, in essence, the main purpose of the government to provide teachers with professional allowances is to increase the competence of the teacher in order to enhance the standard and quality of education so that the teacher can be said to be a professional teacher. In the meantime, according to the Law, teachers and lecturers claim that qualification is part of enhancing the quality and wellbeing of teachers. Therefore, with this credential, it is anticipated that teachers would become trained educators, namely those with a minimum education of S-1/D-4 and competent as learning agents, as demonstrated by having an educational certificate after the proficiency exam. For this practice, teachers are entitled to a salary of one basic salary in the form of a professional allowance from the government. Humans, like teachers, need to fulfill their everyday needs. Teachers working in a variety of classes, teaching after school hours or doing other side jobs are something we used to learn about, since the money they earn is not enough to fulfill their everyday needs. It is hoped that this professional allowance would be able to inspire and empower teachers to continue to enhance their competence and professional success in the performance of their duties as educators, teachers, mentors, directors, trainers and assessors of their students.

According to Aedi [7], there are three concepts relating to supervision, namely (1) supervision (2) supervision and (3) inspection (Kristiawan et al, 2019). Supervision shall include inspection tasks, if everything is in compliance with the schedule, the guidelines given and the principles laid down [8]. Another definition states that monitoring of operations ensures that activities are carried out in compliance with plans and objectives [8].

Sagala [9] argues that academic supervision is assistance and resources given to teachers in order to continue learning, enhance the quality of their learning, promote the imagination of teachers to improve together by choosing and revising instructional objectives, teaching materials, models and methods. Evaluation of teaching and teaching in order to increase the standard of learning, education and curricula in the production of teaching and learning well in order to produce better results.

As a result, the role of a teacher is very dominant in shaping students into skilled human beings, without reducing or removing other roles and functions, the performance of teachers as performers of duties and obligations as educators is one of the factors that plays an important role in the success of education [10].

The head of the madrasah, as a center of leadership, must be able to coordinate and handle all activities 
within a curriculum that is guided, centered and has undergone a number of very significant improvements. According to Susanto [11], a leader is a person who has skills and strengths, in particular skills/benefits in one field, so that he can persuade other people to carry out such tasks together in order to achieve one or more goals. The madrasah Principal plays an important role in enhancing teacher performance in order to be more enthusiastic and professional in teaching or developing knowledge transfer to students.

According to Djaali [12], the success of educators and educators, in particular teachers, is decided not only by academic qualifications and competencies, but also by an appropriate level of well-being, by inspiring teachers to perform their professional duties seriously. The principal of the madrasah is responsible for the effective execution of educational activities through the implementation of school administration in all its content. We can see the important role of teacher supervision and allowances in enhancing teacher performance, which in turn improves the standard of education in schools and madrasahs. The role of teachers in improving the standard of education in schools or madrasahs must be prioritized and very significant. Good teacher success would also help a good learning process. In order to generate good human capital at the end of the day, the standard of education will also improve by itself.

As for the problems that occur at the State Senior High School 1 Prabumulih, i.e. the output of teachers that is still poor, it is proven that the results of the academic supervision of the head of the madrasah are obtained from the data, teaching staff to provide students with learning is often less desirable, so that students are less enthusiastic about listening to the learning material. Then there are also some teachers who have not made learning tools, even though they must exist because, as our teaching guide, many teachers do not make learning tools themselves, but copy and paste and pay/purchase from others. Whereas teachers who have earned the professional allowance are said to be professional teachers, but in fact they are the opposite. There will then be a polemic, either directly or indirectly, that is prone to influencing the performance of the teacher concerned. There is also a need for transparent and firm compliance actions in the execution of the activities. This is what makes researchers involved in carrying out research. This research is looking at the effect between the independent variable and the dependent variable. Quantitative approach is an analysis aimed at finding relationships and describing the causes of change in observable social facts [13]. Quantitative analysis is intended to be research that is used to solve problems by careful calculation methods for certain variables, in order to produce generalizable results, regardless of time and condition, as well as the type of data obtained, in particular quantitative data [14].

\section{METHODS}

This research will be conducted at MA Negeri 1 Prabumulih City in November 2020. This study is a research which uses quantitative methods. The population of this sample was 54 teachers from MA Negeri 1 Prabumulih City. Research is characterized as a data collection and analysis process that is carried out systematically and logically in order to achieve certain objectives. Data collection and analysis shall use both quantitative and qualitative, experimental and nonexperimental, interactive or non-interactive scientific methods [15]. The methodology used in this study is quantitative. The methodology used in this study is quantitative. This research is looking at the effect between the independent variable and the dependent variable. Quantitative approach is an analysis aimed at finding relationships and describing the causes of change in observable social facts [13]. Quantitative analysis is intended to be research that is used to solve problems by careful calculation methods for certain variables, in order to produce generalizable results, regardless of time and condition, as well as the type of data obtained, in particular quantitative data [14].

\section{RESULTS AND DISCUSSION}

\section{The Impact of Professional Teacher Allowances on Teacher Results}

Based on the results of the t-test measurement, it is calculated that the importance of significance is 0.000 . Since the significant value (probability) is less than $0.05, \mathrm{H} 0$ is rejected. This means that Ha is accepted, so that the professional allowance of the instructor has the effect of $\mathrm{X}_{1}$ on $\mathrm{Y}$ of $0.000<0.05$ and the count of 9.495> of table 1.673, so that it can be inferred that Ha1 is accepted, which means that there is an impact between $\mathrm{X}_{1}$ and $\mathrm{Y}$.

As long as researchers carry out research, what the government hopes and learns by having a professional allowance is still far from real standards. In reality, the quality of teachers in Indonesia is still low, and the poor quality of teachers in Indonesia can be seen from the feasibility of teaching teachers. The cause of low teacher eligibility for teaching is the history and skill of the teacher, as there is an indifference or indifference to improving the standard of education, as well as being affected by the low honorarium or compensation of honorary teachers, which is a scourge of problems in educational institutions. This could be due to a lack of optimization of the government's success in developing the welfare economy of teachers as a teaching career. In 
the meantime, one of the things that decides school priorities is the success of the instructor. Teacher success is an absolute necessity for the development of a quality education and system. However, the presence of a professional allowance for teachers makes teachers more excited and inspired to carry out their responsibilities and duties as teachers, e.g. to plan learning materials, to attend school faithfully and on time.

\section{The Impact on Teacher Success of Principal Academic Supervision}

Based on the results of the t-test measurement, the significance value is considered to be 0.010 . Since the significant value (probability) is less than 0.05 , Ho is denied. This means that $\mathrm{Ha}$ is accepted, so the academic supervision of the principal has the effect of $\mathrm{X}_{2}$ on $\mathrm{Y}$, which is $0.002<0.05$, and the value of $t$ count is $1.908>$ $\mathrm{t}$ table is 1.673 , so that it can be inferred that $\mathrm{Ha} 2$ is accepted, which means that there is a major impact between $\mathrm{X}_{2}$ and $\mathrm{Y}$.

During the research process, the academic supervision of the principal of the madrasah was the issue that occurred at State Senior High School 1 Prabumulih, that is, the output of the teacher was still poor, and the teacher's ability to provide students with learning was often less appealing, so that students were less enthusiastic about listening to the learning materials offered. Then there are also some teachers who have not made learning tools, even though they must exist because, as our teaching guide, many teachers do not make learning tools themselves, but copy and paste and pay/purchase from others. Whereas teachers who have earned the professional allowance are said to be professional teachers, but in fact they are the opposite. There will then be a polemic, either directly or indirectly, that is prone to influencing the performance of the teacher concerned. There is also a need for transparent and firm compliance actions in the execution of the activities. This is what keeps researchers involved in doing research. Some teachers are only involved while they are supervised, e.g. in the preparation of equipment or in the administration of classes. Based on this interpretation, the issues found are that there are teachers who have not completed the learning administration on a regular basis, such as the Lessons Plan (RPP). When licensed teacher supervision is done by administrators, there are still teachers who are certified educators, but the learning administration is incomplete.

\section{The Effect of Teacher Professional Allowances and Instructional Supervision of the Principals of Madrasah on Teacher Performance}

Based on the significance value for the effect of $\mathrm{X}_{1}$ and $\mathrm{X}_{2}$ at the same time or together on $\mathrm{Y}$, it is equal to $0.000<0.05$ and the value of Fcount 50.283> Ftable
3.17, so that it can be inferred that $\mathrm{Ha} 3$ is acknowledged, which means that there is an effect of $\mathrm{X}_{1}$ and $\mathrm{X}_{2}$ together. It's against $\mathrm{Y}$.

During the study, the researcher noticed that during the research process, the academic supervision of the principal of the madrasah was the problem that occurred at State Senior High School 1 Prabumulih, that is, the output of the teacher was still low, and the teaching of teaching to students was often less appealing, so that students were less enthusiastic about listening to the apprentice. Then there are also some teachers who have not made learning tools, even though they must exist because, as our teaching guide, many teachers do not make learning tools themselves, but copy and paste and pay/purchase from others. Whereas teachers who have earned the professional allowance are said to be professional teachers, but in fact they are the opposite. There will then be a polemic, either directly or indirectly, that is prone to influencing the performance of the teacher concerned. There is also a need for transparent and firm compliance actions in the execution of the activities. This is what keeps researchers involved in doing research. Some teachers are only active when they are supervised, e.g. in the preparation of equipment or in the administration of classes. Based on this interpretation, the issues found are that there are teachers who have not completed the learning administration on a regular basis, such as the Lessons Plan (RPP). When licensed teacher supervision is done by administrators, there are still teachers who are certified educators, but the learning administration is incomplete.

\section{CONCLUSION}

Based on the results of the study, the following conclusions can be drawn: 1) the professional allowance of the instructor determines the performance of the teacher on the basis of the results of the t-test review. This shows that there is an impact of the teacher allowance on the output of teachers in MA Negeri 1 Prabumulih City responded to the first hypothesis; 2) the academic supervision of the principals of the madrasah shall have an effect on the performance of teachers on the basis of the results of the t-test review. This indicates that there is an impact of the principal's academic supervision on the performance of teachers at State Senior High School 1 Prabumulih City responded to the second hypothesis; 3) teacher's professional allowances and academic supervision of madrasah principals have a common effect on the performance of teachers based on the results of the F-test review. This shows that the effect of teachers' professional allowances and academic supervision of madrasah principals on the performance of teachers in MA Negeri 1 Kota Prabumulih responded to the third hypothesis. 


\section{AUTHORS' CONTRIBUTION}

Sumartini: designed and performed experiments and analysed data. Happy Fitria and Rohana: Proofing.

\section{ACKNOWLEDGMENTS}

Our deepest gratitude goes to Teachers in MI Negeri 1 Prabumulih, Chancellor of Palembang PGRI University, Director of the Postgraduate Program of PGRI Palembang University and the Education Management Study Program of PGRI Palembang University, who have supported us in doing this extraordinary thing. This project is funded independently. We also want to thank our Education Management friends who helped us a lot in a short time frame to complete this project.

\section{REFERENCES}

[1] Asvio, N., Yamin, M., \& Risnita. (2019). Influence of Leadership Style, Emotional Intelligence and Job Satisfaction toward Organizational Commitment (Survey at SMA Muhammadiyah South Sumatera). International Journal of Scientific \& Technology Research 8 (8).

[2] Kasmir. (2018). Manajemen Sumber Daya Manusia [Human Resource Management]. Depok: Rajawali Pers.

[3] Khasanah, U., Kristiawan, M., \& Tobari. (2019). The Implementation of Principals' Academic Supervision In Improving Teachers' Professionalism in the State Primary Schools. International Journal of Scientific \& Technology Research, 8(8).

[4] Hanim, H., \& Rahmadoni, J. (2020). Determination of Lecturer Reception Using Analytical Hierarchy Process (AHP). Journal of Applied Engineering and Technological Science (JAETS), 1 (2), 136141 .

[5] Maseleno, A., Ayshwary, B., Ivanova, T. N., Hashim, W., Nguyen, P. T., Shankar, K., Kristiawan, M., Huda, M. (2019). General Theoretical and Philosophical Aspects of Modern Education. Aspectos Teóricos y Filosóficos Generales de la Educación Moderna. Revista San Gregorio 2019, No. 32 Special Issues August.

[6] Muslich. (2007). KTSP Pembelajaran Berbasis Kompetensi dan Kontekstual [KTSP CompetencyBased and Contextual Learning].Jakarta: Bumi Aksara.

[7] Aedi. (2014). Pengawasan Pendidikan: Tinjauan Teori dan Praktik [Educational Supervision: An
Overview of Theory and Practice]. Jakarta: Rajawali Pers.

[8] Kristiawan, dkk. (2019). Supervisi Pendidikan [Education Supervision]. Bandung: Alfabeta.

[9] Sagala. (2010). Supervisi Pembelajaran dalam Profesi Pendidikan [Supervision of Learning in the Educational Profession]. Bandung: Alfabeta.

[10] Suharsaputra. 2018. Supervisi Pendidikan [Education Supervision]. Bandung: PT Refiika Adita.

[11] Susanto. (2018). Teori Belajar \& Pembelajaran di Sekolah Dasar [Theory of Learning \& Learning in Primary Schools] Jakarta: Prenadamedia Group.

[12] Djaali. (2007). Psikologi Pendidikan [Educational Psychology]. Jakarta: Bumi Aksara.

[13] Winarni. (2018). Teori dan Praktik Penelitian Kuantitatif. Kualitatif [Theory and Practice of Quantitative Research. Qualitative]. Jakarta: Bumi Aksara.

[14] Arifin. (2012). Evaluasi Pembelajaran [Learning Evaluation]. Bandung: Bandung: PT. Remaja Rosdakarya Offset

[15] Sukmadinata. (2013). Metode Penelitian Pendidikan [Educational Research Methods]. Bandung: PT. Remaja Rosdakarya. 